\title{
Assessing the genealogical value of a potential new source: the value of the Equitable Life Assurance Society archives, 1762-1835
}

Received: 18 December 2018

Accepted: 22 January 2019

Additional information is available at the end of the article.

KEYWORDS: life assurance; life insurance; archives

\section{Elizabeth Bowsher}

\begin{abstract}
The archives of the Equitable Life Assurance Society (1762-1835) at the Institute and Faculty of Actuaries, London, contain policy records which include date and place of birth and occupational information. These records predate the creation of the General Register Office and were created at a time when personal records tended to be scarce. The research question was whether the policy records had a value as a potential genealogical source. Case studies, genealogical standards, archival appraisal criteria and demographic analysis were used to objectively assess the genealogical value of the records. The appraisal considered them from the perspectives as both prima facie genealogical records and as a contextual resource for a genealogical inquiry. The study found that the records had evidential value as a complementary genealogical source. Evaluation suggested that the quality of the records was good in terms of reliability, consistency with other primary sources and completeness. They also provided information that was not available in other traditional sources. Through case studies it was demonstrated that information about life insurance could bring an additional dimension to the appreciation of people's lives in the late eighteenth and early nineteenth centuries.
\end{abstract}

Introduction: the Equitable Life Assurance Society archives, 1762-1835

The focus of the study was the archives of the Equitable Life Assurance Society, 1762-1835, held by the Institute and Faculty of Actuaries in London. Many of the records in the archive are historically significant to the actuarial profession. The Society for Equitable Assurances on Lives and Survivorships (Equitable) was created in 1762. It transformed the nature of life assurance by introducing insurance premiums based on the actuarial analysis of mortality statistics. It was the first life insurance society to conduct actuarial valuations and distribute reversionary bonuses to members. It also coined the term 'actuary'. ${ }^{1}$ In 1800 life insurance in Britain was limited to approximately 10,000 customers, holding just over $£ 10 \mathrm{~m}$ cover, half of which was provided by Equitable. ${ }^{2}$

Although insurance policy records have been used in historical research, they are acknowledged to be an underutilised resource; similarly, references to life insurance policy records as a genealogical source are few and far between. ${ }^{3}$ The research question was whether the Equitable policy records had a value as a potential genealogical source.

\section{Method}

The archive was 'weeded' in 1925. Consequently, many record series are incomplete and the information for a specific policy found in one record series is likely to be missing from others. The archive is split between two repositories in London: the Institute and Faculty of Actuaries (IFoA) Library and the London Metropolitan Archives (LMA). In general, pre-1830 items are held at the IFoA and post-1830 items at the LMA. ${ }^{4}$ The IFoA archive was chosen as the focus for the study because the records predate the introduction of civil registration and the 1841 census.

Policy records, described as Ticket Books (TBs), were selected as the primary source for the study as they provided the most comprehensive genealogical source in the archive. ${ }^{5}$ The tickets (Figure 1) were printed proforma records which were used to record the names, occupations, addresses, places and dates of birth, age at entry, class of assurance, date of proposal and names of private referees, and health information of individuals who were proposed for life assurance policies. There were three tickets per page, verso and recto. Numbered pages were bound 
into date sequential 'Ticket Books'. The archive contained five TBs. Each volume covered approximately five years and contained an estimated 1500 individual tickets. (The periods covered by the Ticket Books in the archive are: 1772-1777 ('TB1'), 1777-1782 ('TB2'), 1798-1800 ('TB3'), 1824-1829 ('TB4'), and 1829-1835 ('TB5').)

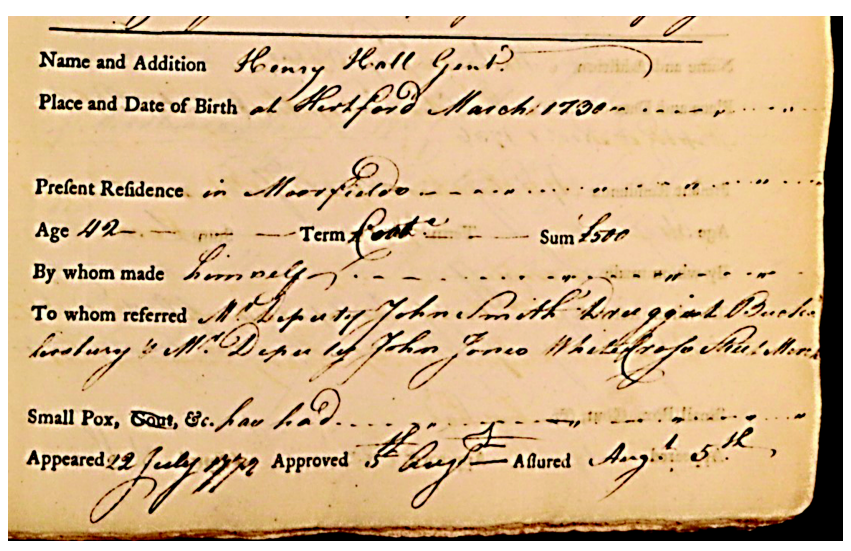

Figure 1. 'Ticket' example. ${ }^{6,7}$

The TBs for the earliest available period, 1772-77 (TB1) and the latest available period, 1829-35 (TB5) were selected for the study so that they could be compared longitudinally. This also theoretically allowed TB information to be connected to other record series in the archive. A total of 3543 TBs entries were transcribed and entered into an Excel database: 1880 TB1 and 1663 for TB5. Information was transcribed from all proforma fields. The completeness of the entries varied: key information, such as age, was missing in some tickets; additional detail was provided by margin notes in others. All of the ticket entries in TB1 and TB5 were analysed to establish the demographic profile of the individuals proposed for policies. A $1 \%$ sample of tickets was selected to develop as case studies. The case study tickets were randomly selected, subject to being proportionate to the number of tickets and the social and occupational mix of each volume. Case studies were developed using genealogical techniques.

\section{Appraisal}

Whether a particular record has 'genealogical value' can be a subjective judgement which depends on the nature of a source and the specific inquiry. ${ }^{8}$ Genealogical standards and archival appraisal criteria were brought together into an evaluative framework so that the records could be assessed objectively as a genealogical source., ${ }^{9,10}$ The broad criteria used were:

1. Source quality

(a) Using genealogical standards, how reliable were the TBs?

(b) How did the TBs compare to other available primary sources? ${ }^{11}$

(c) How 'complete' were the TBs?

2. Added value

(a) What did the TBs tell us that we did not know before?

(b) Did the TBs bring new context to other information? ${ }^{12}$

3. What was the value of other records in the Equitable archive?

4. What is the demographic profile of the individuals proposed for policies in TB1 and TB5?

\section{Source quality}

\section{Reliability of the source}

Elizabeth Shown Mills' two principles for assessing the reliability of genealogical sources ${ }^{13}$ are that sources should be evaluated in order to assess probable reliability, credibility and relevance; and that the knowledge of the informant and the relevance and adequacy of the evidence should be evaluated based on the research question.

The process for making life assurance policies was set out in Equitable's byelaws. The actuary made a daily record of applicants. ${ }^{14}$ Proposers and witnesses were formally required to attest to 'the Age, State of Health, Profession, Occupation, and other circumstances' of the proposed 
life. ${ }^{15}$ Eight days were required to elapse between proposing a policy and granting the insurance in order that 'necessary inquiries' could be made. ${ }^{16}$ The fact that the enquiries were made was evidenced by the presence of a small number of sample certificates and correspondence within the TB pages and by annotations on tickets confirming sight of certificates. Other evidence cited included cross-references to other credible sources, e.g. 'English Peerage' (see Case study summary 4). Taken together, the evidence suggested that the TBs were a credible and reliable source. ${ }^{17}$

How did the source compare to other available primary sources?

Online genealogical primary sources were used to develop the case studies and helped to validate the TBs' information. The consistency of the information given in the tickets against other primary source birth information is shown in Table 1.

Table 1. Consistency of Ticket Book birth details against other primary sources.

\begin{tabular}{crrrr}
\hline Ticket Book & Certain $^{*}$ & Highly probable $^{\dagger}$ & No comparable primary source $^{\ddagger}$ & Ambiguous information $^{\text {§ }}$ \\
\hline TB1: $\mathbf{1 7 7 2}-\mathbf{7 7}$ & 2 & 10 & 6 & 1 \\
TB5: $\mathbf{1 8 2 9}-\mathbf{3 5}$ & 6 & 8 & 2 & 0 \\
Total & $\mathbf{8}$ & $\mathbf{1 8}$ & $\mathbf{8}$ & $\mathbf{1}$ \\
& $(\mathbf{2 3} \%)$ & $\mathbf{( 5 1 \% )}$ & $\mathbf{( 2 3 \% )}$ & $\mathbf{( 3 \% )}$ \\
\hline
\end{tabular}

Source: TB1 and TB5: Case studies.

*Certain: Details match primary source exactly.

${ }^{\dagger}$ Highly probable: Details are sufficiently similar to the primary source that they can be reasonably explained, e.g. by differences between birth or baptism dates or Old Style calendar.

${ }^{\ddagger}$ No comparable primary source: Following reasonably exhaustive searches relevant primary source baptism or birth records were not located for the individual. ${ }^{\S}$ Ambiguous information: Information agrees in part, but a conflict requires resolution e.g. date of birth information agrees, but place of birth information conflicts.

The analysis showed that in the case studies $74 \%$ of the TB information had a certain or probable match to other sources, giving the records a high corroborative value. ${ }^{18}$

\section{How 'complete' were the TBs?}

Missing or incomplete data is relevant to the reliability and usefulness of a source. From a genealogical perspective, a list of names with no qualitative information, such as year or place of birth, may mean it has no evidential value. Table 2 shows that the completeness of birth information for the totality of the TB records in TB1 and TB5 ranged from 90-99\%, suggesting that the TBs were a potentially useful source.

Table 2. Completeness of date and place of birth information.

\begin{tabular}{lrr}
\hline Ticket Book & Date of birth or age information & Place of birth information \\
\hline TB1: 1772-77 & $99.5 \%$ & $90.1 \%$ \\
TB5: 1829-35 & $99.4 \%$ & $99.5 \%$ \\
\hline
\end{tabular}

Source: TB1 and TB5. Analysis of all tickets in both volumes.

\section{Added value}

What did the TBs tell us that we did not know before?

If the tickets simply replicate the information which can be found in existing online resources, then they may have very little added value as a genealogical source. The study showed that some tickets contained information that was not otherwise located in reasonably exhaustive searches. For Francis Seymour Cosby (Case study summary 1), a month, year and place of birth was provided by the ticket, alongside evidence that he was in London in 1772. This information was not found in other available sources.

\section{Case study summary 1: additional birth and other information for Francis Seymour Cosby}

Ticket Detail: Ticket Book 1, proposed 12 August 1772

Name and Addition: Francis Seymour Cosby Esq. Officer in Middx [Militia]

Place and Date of Birth: at Vicars Town Queens County Ireland May 1749

Present Residence: Villers Street St Martin in the Fields 
It seems likely that Francis was the son of Francis Cosby (d. 1783) and Ann Piggott (d. 1783), whose known children included a son, Francis Seymour Cosby. ${ }^{19,20,21}$ The Cosbys were the descendants of Francis Cosby, an English soldier who arrived in Ireland in the sixteenth century and secured his social position by marrying Lady Mary Seymour (widow of Sir Henry Payton), the daughter of the first Duke of Somerset. ${ }^{22}$ 'Our' Francis' middle name may therefore have family significance.

TB1 gave Francis' birth details as at 'Vicars Town Queens County Ireland, May 1749'. A branch of the Cosby family became known as 'of Vicarstown', matching the information in TB1 for Francis. ${ }^{23}$ Francis' parents married in Dublin, Ireland in April 1730 and the stated birth dates for two of his siblings are 1731 and 1742, which makes the ticket birth information plausible. Francis' date of birth is not given in other sources, although one suggests a rather large window of 'between 1695 and 1756 '. ${ }^{24}$ Another source suggests that Francis died in 1776 and others that he died at an indeterminate date without issue..$^{25,26,27}$

The ticket provides evidence that Francis was in London in around 1772, enabling newspaper and Freemason references to be linked to him. ${ }^{28,29,30}$ A Francis Seymour Cosby was also listed as a 'Jerquer', or a customs officer, in the City of London in

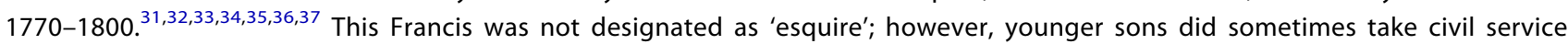
posts: for example, the Duke of Manchester's brother, Lord Montague, was a customs collector in London. ${ }^{38}$

Information from tickets helped to establish the identity of the one-time Commissary General of Stores in Quebec, John Christopher Roberts, and to connect him to other facts (Case study summary 2). The case study illustrates the potential of the tickets to connect records and correct errors made in the absence of key facts.

\section{Case study summary 2: clarifying erroneous information for John Christopher Roberts}

Ticket Detail: Ticket Book 1, proposed 15 July 1772

Name and Addition: Jno Christr Roberts. Secretary to the Province Quebec

Place and Date of Birth: on Tower hill $30^{\text {th }}$ Octr 1738

The ticket states that John Christopher Roberts, 'Secretary to the Province of Quebec' was born at Tower Hill on 30 October 1738. Other Equitable archive documents (see below) describe John as 'Commissioner of Stores at Quebec'. John's baptism was registered in the Presbyterian Registers at Dr William's Library on 28 November $1738 .{ }^{39}$ The name and baptism date were consistent with the information in the ticket stating that he was born at Tower Hill on 30 October 1738. His parents were named as Gaylard and Ann Roberts. John's will and The Gazette recorded that John Christopher Roberts, formerly Government Storekeeper at Quebec, died in 1805 in Stettin, Pomerania. ${ }^{40,41}$ The Oxford Dictionary of National Biography (ODNB) described John Christopher Roberts, secretary of the province of Quebec, as the son of John Roberts (1711/12-1772), politician, and stated that he died in $1810 .{ }^{42}$ The TB information connects the identity, parents and death date for John Christopher Roberts, Secretary to the Province of Quebec. It would now be possible to amend the reference to John Christopher Roberts in the ODNB entry for John Roberts.

\section{Did the TBs bring new context to other information?}

The nature of the early life assurance market has been considered in a number of studies. ${ }^{43}$ 'Own life' policies, i.e. policies taken out by a person on their own life, have been used as a proxy for policies used to protect dependents to provide them with financial support in the event of the named person's death; 'third-party' policies, i.e. policies that were taken out on the life of another person, have been used as a proxy for creditor-held policies, taken out as collateral against debt. ${ }^{44}$ The tickets state by whom the policy was made, so it was usually reasonably clear whether the ticket was an 'own life' or a 'third-party' policy proposal. The information given on the ticket therefore provided some indication of the likely purpose of the life assurance proposal. The analysis of all the tickets in TB1 and TB5 showed a marked shift from life assurances being made by third parties on the lives of others (73\% in TB1), towards assurances being made by individuals on their own lives (77\% in TB5). Applying this logic to the TBs suggests that assurances taken out with the Equitable shifted away from them mainly being used in TB1 (1772-77) as collateral for debts towards their mainly being used in TB5 (1829-35) for providential purposes to protect dependents. The case studies also provided supporting inferences for the possible reasons for taking out policies. An example of a life assurance most likely taken out as financial protection for a family is illustrated by the case study for Richard Hardinge Stewart. Recently widowed Richard had four small children to support and took out a policy on his own life (Case study summary 3). 
Case study summary 3: life assurance as financial provision for the family of Richard Hardinge Stewart

Ticket Detail: Ticket Book 5, proposed 21 May 1834

Name and Addition: Richard Harding Stewart of the war office

Place and Date of Birth: Featherstone $B^{9 s} 22^{\text {nd }}$ May 1793

Present Residence: 10 Grove Street Camden Town

Richard was a civil servant at the War Office. He married in May $1826 .{ }^{45}$ His wife, Caroline, died in August 1833, aged only twenty-eight, within days of the birth of their youngest daughter. ${ }^{46,47}$ Richard was left to bring up four children aged under the age of eight. In May 1834 Richard took out a policy on his own life for $£ 1000$ [about $£ 1.2 \mathrm{~m}$ income value in $2017^{48}$ ]. It seems highly likely that the policy was intended as financial provision for Richard's young family. Richard died in April 1872, aged seventy-eight. ${ }^{49,50}$ By then his children were mature adults but they were able to benefit from Richard's life assurance policy which paid out $£ 1780$ on his death [about $£ 1.2 \mathrm{~m}$ income value in 2017]. ${ }^{51,52}$

An example of when life assurance was most likely taken out as collateral against a debt is illustrated in the case study for Lionel Damer (Case study summary 4). In TB1 Lionel was the subject of three policies made on his life by third parties. Other circumstantial information tends to support the inference that the policies were intended as security for his creditors.

\section{Case study summary 4: life assurance used as security against debts by Lionel Damer}

Ticket Detail: Ticket Book 1, proposed 10 May 1775

Name and Addition: The Hon ${ }^{\text {ble }}$ Lionel Damer third son of Lord Milton

Place and Date of Birth: $16^{\text {th }}$ Sepr 1748 vide English Peerage

Present Residence: Dean Street May Fair

Lionel Damer was the third son of Baron Milton, the first Earl of Milton and Lady Caroline Sackville (the daughter of the first Duke of Dorset). ${ }^{53,54}$ In May 1775 Joseph Sparkes, a director of the East India Company, ${ }^{55}$ made an insurance of $£ 400$ [about $£ 747,000$ income value in 2017] against the continuation of Lionel's life. On the same day, Wickens Hodges of Hoxton Square also made a policy against Lionel's life for $£ 400$ for seven years. In March 1776 Nathaniel Burrough of Suffolk made a policy against Lionel's life for $£ 600$ for seven years. John Damer, Lionel's older brother, owed more than $£ 70,000$ [about $£ 130 \mathrm{~m}$ income value in 2017] to various creditors by 1776, which was when he committed suicide. John was described as 'a felon and a rake ...[who] ... would inherit his father's income of $£ 30,000$ a year. ${ }^{.56}$ It was widely said that the debt was accumulated at least in part by Lionel and their other brother, George. ${ }^{57}$ The fact that several people took out policies on Lionel's life, and the circumstances associated with Lionel's older brother's debts, strongly infer that the policies taken out against Lionel's life were intended as collateral against debts.

Several contemporary commentators suggested situations when the making of a life assurance might be a sensible precaution. Examples included: when receiving money at a future time depended on a person attaining a specified age, marrying or having children; or where a loan was secured against an entailed estate; or where profits from an enterprise would not materialise for a year or two; or when inheritance depended on a person outliving an elderly relative. ${ }^{58}$

An example of a policy which appears to have been taken out as a precaution against a death occurring before a person was old enough to receive money was that of Mary Capp, a nineteen-year-old bride whose husband took out a policy on her life until after her twenty-first birthday (Case study summary 5).

Case study summary 5: life insurance to protect against the death before inheritance of Mary Capp nèe Parkinson

Ticket Detail: Ticket Book 1, proposed 21 August 1776

Name and Addition: Mary Capp, wife of Will ${ }^{\mathrm{m}}$ Capp Gent 
Place and Date of Birth: Loughbro' Leicestershire $22^{\mathrm{d}}$ April

Present Residence: Loughbro' afsd

Mary Parkinson was orphaned at the age of fifteen when her father died in $1773 .{ }^{59}$ Her father died intestate and administrators were appointed until such time as she attained her majority. ${ }^{60}$ In June 1776, Mary, aged nineteen, married William Capp. ${ }^{61}$ In August 1776 William took out a policy on Mary's life for $£ 1000$ for one year [about $£ 1.8 \mathrm{~m}$ income value in 2017]. The insurance covered the period from shortly after her marriage until after her twenty-first birthday in May $1777,{ }^{62}$ which suggests that it was intended to cover the period until she reached her majority and was able to receive funds from either a settlement or an inheritance.

There were also examples of where life assurances appear to have been taken out to provide collateral for new business ventures. Edward Byas was a baker who was establishing himself as a pauper farmer when he took out a life assurance policy in 1833 (Case study summary 6).

\section{Case study summary 6: life insurance to provide security for the business of Edward Byas}

Ticket Detail: Ticket Book 5, proposed 20 November 1833

Name and Addition: Edward Byas, Baker

Place and Date of Birth: St Georges' in the East $8^{\text {th }}$ July 1799

Present Residence: 174 High Street Shoreditch

In November 1833 Edward Byas made a policy on his own life of $£ 400$ [about $£ 520,000$ income value in 2017]. Edward was described in the ticket as a baker. He was also described as a baker in Old Bailey proceedings in $1834 .{ }^{63}$ In April 1833 Edward Byas and his business partner, Sarah Poulain, took out fire insurance for the workhouse in Bear Lane, Southwark, where they had a pauper farm. ${ }^{64,65}$ In 1840 he was the 'proprietor for an establishment for the maintenance of people who are supported by their friends'. ${ }^{\prime 6}$ By 1841 Edward was the proprietor of Grove House Asylum and his business partner, Sophia Poulain, was the matron. ${ }^{67,68}$ Edward married Mary Ann Lovie in 1836 , three years after the life assurance was taken out. ${ }^{69}$ The timing of the policy strongly implies that it was associated with a new business venture, and not as family provision. Edward died in May $1866 .{ }^{70,71}$ His executors made a claim on his policy, which by then was worth $£ 572$ [about $£ 463,000$ income value in 2017]. ${ }^{72}$

On other case studies the presence of a life insurance application raised questions about the nature of personal and financial relationships between individuals. A policy proposed on the life of Catherine Bonell raised questions about the nature of the relationships between her, her second husband and another man (Case study summary 7).

\section{Case study summary 7: life assurance - questions about personal and financial relationships of Catherine Bonell}

Ticket Detail: Ticket Book 1, proposed 9 April 1777

Name and Addition: Catherine Bonell, Widow born in Fenchurch Street Jany 7th 1741 OS but now of Sutton Coldfield

Place and Bate of Birth: Warwickshire beyond the Life of Tho Sainsbury Born at Lavington Wilts $25^{\text {th }}$ Decr 1732 but now of

Present Residence: Ludgate Hill London Tobacconist

Age: 37 bey ${ }^{d} 44$ Term: Surv ${ }^{r}$ Sum: $£ 500$

By whom made: Thos Sainsbury aforesaid

To whom referred: Mrs Plaxton No 46 Titchfield Street Mr Jackson apothecary Ivey Lane

[Transcribed as per ticket]

Catherine Bonell was a widow and the heiress to estates in Nottinghamshire and Cambridgeshire. ${ }^{73,74}$ In April 1777 Thomas Sainsbury proposed a survivorship policy against Catherine's life for $£ 500$ [about $£ 890,000$ income value in 2017], i.e. the assurance would be paid if she outlived him. While Thomas Sainsbury was described in the ticket as a tobacconist, he was known as an importer of tobacco and had a large warehouse in Blackfriars. ${ }^{75}$ He was a master of the Company of Bowyers from 1774-76, an alderman of the City of London 
from 1778-95, Sherriff of London and Middlesex in 1780, Lord Mayor in $1786 .{ }^{76}$ He was also a director of the Equitable in $1786-87 .{ }^{77,78}$ When he died in 1795 his will showed that his personal estate exceeded $£ 55,000$ [about $£ 75 \mathrm{~m}$ income value in 2017]. ${ }^{79,80}$

One of Catherine's referees in the life assurance proposal was a Mrs Plaxton of Titchfield Street, London. A marriage between Catherine and a William Plaxton was planned in May 1777 but did not take place. ${ }^{81,82}$ Catherine and William Plaxton then married in 1779, which was after Catherine had come into her inheritance. ${ }^{83,84,85}$ The life insurance proposal was 'disapproved' so no policy was made. However, the associations between the individuals and the wider circumstances raise questions about the intended purpose of the proposed assurance and the personal and financial connections which may have existed between Thomas, Catherine and William.

Thomas's second wife, Ann, died in January $1776 .{ }^{86,87}$ In October 1777 Thomas married his third wife, Mary Evebugh, at St Martin Ludgate. $^{88}$ The timing of Thomas's marriages and of Catherine's planned and actual marriage to William Plaxton tends to preclude a romantic involvement between Thomas and Catherine. From June 1765 to October 1780 William Plaxton was 'One of the Gentlemen Ushers Quarter Waiters in Ordinary to his Majesty'. ${ }^{89,90}$ In 1780 his salary was $£ 10$ a year, with board wages of $£ 40 .{ }^{91}$ Other information suggests that following their marriage William borrowed money against Catherine's estate, using her life as security. ${ }^{92,93}$ Further research has identified court proceedings which appear to relate to the individuals associated with the proposed policy: these include the cases of Bonell v Plaxton in $1778 ;{ }^{94}$ Plaxton v Sainsbury in $1782 ;{ }^{95}$ Bonell v. Plaxton in $1791 ;{ }^{96}$ and Bonell v Harborne in $1794 .{ }^{97}$ More work is being done to understand the connections and circumstances surrounding this life assurance proposal.

Sometimes people used life assurance to cover relatively short periods of time. This raises questions about their reasons for doing so, particularly where the policies do not appear to have been made as security for loans. John Christopher Roberts (Case study summary 2, above) was the subject of ten Equitable life assurance policies made between 1768 and 1777, eight of which were taken out by him on his 'own life'..$^{98,99}$ In 1768 John was appointed as Commissary for Stores to Quebec. ${ }^{100}$ This was a significant role and he was responsible for keeping the British forces in Quebec supplied with provisions. ${ }^{101,102}$ (However, the first reference cited here erroneously states 'As far as can be ascertained, the office of commissary general to the forces in Canada was held by one man only, Nathaniel Day, who was commissioned 20 March, 1776, and apparently occupied the post until the latter part of 1777'. There were at least two office holders prior to Mr Day (including John Christopher Roberts). TNA also references returns being made by Mr Day in that role up to and including 1781.) In 1775 the events which led up to the Battle of Quebec in December would have made John's role especially important. Looking at the timing of John's policies against events suggests that the timing of some policies may have had a particular significance (Case study summary 8 ).

\section{Case study summary 8: life assurance policies and life event timeline of John Christopher Roberts}

On 29 June 1768 John was appointed to the position of Commissary General of Stores and Provisions at Quebec, replacing Henry Ellis. The appointment was made for the term of John's natural life at a salary of $£ 140 .{ }^{103,104}$ John remained in London and carried out his functions through appointed deputies who were resident in Quebec. ${ }^{105}$ In July 1768 a policy was taken out on John's life by a William Cobb, policy details and identity of William Cobb unknown (policy 1). In January 1770 John took out a survivorship policy against the life of Henry Ellis, the former Commissary General (see above), further policy details unknown (policy 2). 'Averse to being considered an unemployed Person at my Time of my Life ...', John also simultaneously held a position as Clerk and Paymaster of Pensioners to the Military Fund at the East India Company (EIC) from 1770-76. ${ }^{106,107}$ In October 1771 John took out a policy on his own life for $£ 200$ for four months (policy 3). In July 1772 John took out a policy on his own life for $£ 400$ for six months (policy 4). In June 1773 John requested an allowance for his post of Commissary General. ${ }^{108}$ In June 1773 , John also took out a policy on his own life for $£ 300$ for eight months (policy 5). In March 1774 John took out a policy on his own life for $£ 300$ for nine months (policy 6). The Quebec Act was passed in June 1774 and was intended to provide for effective British government in French Canada. It was one of the series of Acts passed by Parliament intended to impose British authority on the American Colonies which became known as the 'Intolerable Acts' and are cited as contributing to the causes of the American Revolutionary War. ${ }^{109,110}$ In February 1775 John took out a policy on his own life for $£ 400$ for six months (policy 7). On 31 March 1775, consequential to the Quebec Act, John's lifetime appointment as Commissary General was officially reconfirmed. ${ }^{111}$ John 'formed ... Plans, entered into Engagements and arranged [his] affairs, in Consequence of so considerable a Body of Troops being sent Thither at the Beginning of [this] Year..112

The American Revolutionary War started in April 1775. In late August 1775 an American expedition set out towards Quebec. By September 1775 two expeditions of American troops began advancing toward the province of Quebec. By early December 1775 American Generals and their men were at the outskirts of Quebec City, demanding the city's surrender. ${ }^{13}$ On 27 December 1775 John took a policy on his own life for $£ 300$ for one year, which he then declined (i.e. he decided not to take it out) (policy 8). The Americans were defeated in the Battle of Quebec on 31 December 1775. ${ }^{114}$ 
The Americans continued to ineffectually bombard Quebec City until March $1776 .{ }^{115}$ In March 1776 John was informed 'that a Mr Day had been appointed Commissary, and that other Persons were about to be appointed Deputy or Assistant Commissaries to [Mr Day] in the ... Province of Quebec', effectively usurping John in his role. ${ }^{16,117}$ John sent a Memorial to the Treasury, setting out his prior legal claim to the office. He also attended almost every Treasury Board meeting for nearly two months. ${ }^{118}$ On 20 March 1776 John took out a policy on his own life for $£ 400$ for nine months, which was forfeited (i.e. John did not pay the premium) (policy 9). In May 1776, following the arrival of a British fleet at Quebec, the Americans retreated from Quebec. ${ }^{119}$

In January 1777 John made a policy on his own life for $£ 400$ for one year (policy 10). On 31 May 1777 the Treasury wrote to John, dismissing his claim. John then consulted seven legal counsel who unanimously supported his legal right as the lifetime holder of the Office of Commissary General. ${ }^{120}$ In December 1777 John asked for a short leave of absence from the EIC in order to resolve his position. ${ }^{121}$ Unfortunately his difficulties were such that he was unable to return to the EIC by the agreed date and he lost his position there. ${ }^{122}$ John's will makes it clear that he never regained his position as Commissary General and that he felt he had been dealt a grave injustice. He died in 1805, unmarried and without children. ${ }^{123,124}$

Further work is being undertaken to understand John's use of life assurance policies during the period $1768-77$ and possible links to financial support provided by his wider family networks, alluded to in John's will.

What was the value of other records in the Equitable archive?

Other Equitable record series were identified and examined to see whether they held further information that would be of use in developing the case studies. ${ }^{125}$ A general limitation was the discontinuity of records resulting from the 1925 weeding of the archive: some records corresponding to the policies in the case study tickets no longer existed; records which were still in existence sometimes added interesting additional information to that in the TBs. This section describes those of most interest in the study.

The Alphabet Indexes is a complete series covering $1762-1829 .{ }^{126}$ They list individuals by name and give index type information on the policies held on their lives, including for policies outside of the period covered by the TBs. They also indicate whether policies had expired, been forfeited or declined, and those which were claimed (see Case study summaries 3 and 6). However, they do not provide date or place of birth information.

The Weekly Court of Directors Minutes for the period $1763-1834$ is a complete series. ${ }^{127}$ In one case study a person's occupation was stated in the Weekly Minutes, but the ticket simply designated him as 'gentleman'. The Minutes also recorded the receipt of death certificates and approvals of payments to executors when a claim was made, including its value.

The Register of Deaths is an actuarial document which contains anonymised information. To use it requires knowledge of the policy number, the age of the individual at the time the policy was taken out, and the death date. ${ }^{128}$ However, it does little more than confirm known information. It is also worth noting that only a minority of policies were claimed: of the nineteen TB1 case studies only three claims were made.

\section{What is the demographic profile of the individuals proposed for policies in TB1 and TB5?}

All the tickets in TB1 and TB5 were analysed to establish the demographic profile of the individuals proposed for policies. Around $90 \%$ of the lives proposed were men, predominantly born and residing in Greater London. In TB1 (1772-77) around 40\% of lives were gentlemen, esquires and nobility, and about $20 \%$ were professionals. In TB5 (1829-35) there was a switch so that only about $10 \%$ of lives were gentlemen, esquires and nobility, while about $30 \%$ were professionals. The individuals proposed for life assurance were predominantly upper-class men, living in London; however, individuals were proposed from a range of occupations, including labourers and servants, and drawn from across the British Isles and other countries. Women and children also featured in the tickets, including married women who sometimes made policies on their own lives or even their husbands' lives. Occasionally entries for women referenced their maiden names, but this was a bonus rather than the norm.

\section{Conclusions}

The broad assessment framework used provided a way to consider the quality of the source, the additional value brought by the records and whether other records in the Equitable archive had further value. The study found that the TBs could have a value as a genealogical resource. The case studies suggested that the value of the tickets was in connecting them with other traditional records. Similarly, the value of other Equitable records arose from being able to link them to the TBs. While the demographic profile of the individuals shown in the tickets is skewed in terms of social class and geography, other individuals do appear.

The archive is relatively unknown. The majority of genealogists would have no cause to seek it out unless they had reason to believe an ancestor had taken out a life assurance policy with the Equitable. The project has created a database of entries from TB1 and TB5. In addition, there are three 
further TBs to be transcribed, potentially providing a further 5000 genealogical records and the opportunity to create an additional genealogical resource. Work is in hand to carry out an extended study across all five TB volumes and to consider whether the transcriptions might help to make the information more accessible in future. Rights to transcribed data are currently exclusively retained by the author.

\section{Acknowledgements}

With grateful thanks to David Raymont, archivist at the Institute and Faculty of Actuaries for his support and assistance.

\section{Citation information}

Cite this article as: Bowsher, Elizabeth (2019) Assessing the genealogical value of a potentia new source: the value of the Equitable Life Assurance Society archives, 1762-1835. Journal of Genealogy and Family History. 3(1). http://dx.doi.org/10.24240/23992964.2019.1234521

\section{References}

1. The Institute and Faculty of Actuaries. Importance of the Equitable Life archive. https://www.actuaries.org.uk/learn-and-develop/research-and-knowledge/libraryservices/historical-collections/archive-equitable-life-assurance-society/importanceequitable-life-archive.

2. Alborn, Timothy L. (2009) Regulated lives: life insurance and British society, 1800-1914. Canada, University of Toronto Press. p. 4.

3. Bowsher, Elizabeth. (2018) What is the value of the Equitable Life Assurance archive, 1763-1835? A genealogical and demographic study. Unpublished MSc Dissertation University of Strathclyde. pp. 26-36.

4. Institute and Faculty of Actuaries. (2007) Equitable Life Assurance Society Archive, 1762-1975. p. 3. https://www.actuaries.org.uk/learn-and-develop/research-andknowledge/library-services/historical-collections/archive-equitable-life-assurancesociety.

5. The Institute and Faculty of Actuaries. Equitable Life Assurance Society Archive $1762-$ 1975: Catalogue. EL4/5/7-11. p. 27. https://www.actuaries.org.uk/learn-anddevelop/research-and-knowledge/library-services/historical-collections/archiveequitable-life-assurance-society.

6. Images: Photograph. Ticket Book 1 - Sample Ticket. May 2018. [Anonymised] Private Collection. Shown with agreement of the Institute and Faculty of Actuaries (RC 000243).

7. The Institute and Faculty of Actuaries. Equitable Life Assurance Society Archive $1762-$ 1975: Catalogue. EL4/5/7-11. p. 27. https://www.actuaries.org.uk/learn-anddevelop/research-and-knowledge/library-services/historical-collections/archiveequitable-life-assurance-society.

8. FamilySearch. (2016) Using the genealogical proof standard in your research (National Institute). https://www.familysearch.org/wiki/en/Using_the_ Genealogical_Proof_Standard_in_Your_Research_(National_Institute).

9. Boles, Frank \& Young, Julia Marks. (1985) Exploring the black box: the appraisal of university administrative records. The American Archivist. 48(2). pp. 121-140. http://americanarchivist.org/doi/10.17723/aarc.48.2. $1414 \mathrm{~g} 624328868 \mathrm{vw}$.

10. Westford Massachusetts. Adaption of Boles and Young appraisal questions. https:// westfordma.gov/DocumentCenter/View/1336/25-Appendix-E-Adaptation-Bolesand-Young-Appraisal-PDF?bidld.

11. Mills, Elizabeth Shown. (1999) Working with historical evidence: genealogical principles and standards. National Genealogical Society Quarterly: Evidence: a special issue. 87(3). pp. 165-184. https://www.historicpathways.com/download/work wthhistevidence.pdf.

12. Strathclyde University. Genealogy to family history: the value of adding context. https://www.futurelearn.com/courses/genealogy/0/steps/13032.

13. Mills, Elizabeth Shown. (1999) Working with historical evidence: genealogical principles and standards. National Genealogical Society Quarterly: Evidence: a special issue. 87(3). pp. 165-184. https://www.historicpathways.com/download/work wthhistevidence.pdf.

14. Morgan, W. (1833) The deed of settlement as the same is inrolled in his majesty's court of king's bench at Westminister, in the year 1765; with the bye-laws and orders. To which are appended reports made on various occasions by the court of directors and nine addresses by W. Morgan. London: Richard Taylor. Clause 35, p. 20. https:// catalog.hathitrust.org/Record/008692004.

15. Morgan, W. (1833) The deed of settlement as the same is inrolled in his majesty's court of king's bench at Westminister, in the year 1765; with the bye-laws and orders. To which are appended reports made on various occasions by the court of directors and nine addresses by W. Morgan. London: Richard Taylor. pp. 8-9. https://catalog. hathitrust.org/Record/008692004.

16. Morgan, W. (1833) The deed of settlement as the same is inrolled in his majesty's court of king's bench at Westminister, in the year 1765; with the bye-laws and orders. To which are appended reports made on various occasions by the court of directors and nine addresses by W. Morgan. London: Richard Taylor. p. 62. https://catalog.hathi trust.org/Record/008692004.

17. Mills. Elizabeth Shown. (2001) Professional genealogy: a manual for researchers, writers, editors, lecturers, and librarians. Baltimore: Genealogical Publishing Company. p. 337. www.books.google.co.uk.

18. Mills, Elizabeth Shown. (1999) Working with historical evidence: genealogical principles and standards. National Genealogical Society Quarterly: Evidence: a special issue. 87. pp. 181-182. https://www.historicpathways.com/download/workwthhistevidence.pdf.

19. Burke's Peerage. Burke's Landed Gentry Irish Family Records. 'Cosby', p. 281. www. Burkespeerage.com.

20. The Peerage. Francis Cosby. http://www.thepeerage.com/p37462.htm\#i374620.

21. Stirnet. Cosby 1. https://www.stirnet.com/genie/data/british/cc4aq/cosby1. php\#vic1.

22. Lennon, C. (2008) Oxford Dictionary of National Biography: Cosby, Francis (d. 1580), soldier and planter in Ireland. http://www.oxforddnb.com/view/10.1093/ref:odnb/ 9780198614128.001.0001/odnb-9780198614128-e-6368.

23. Burke's Peerage. Burke's Landed Gentry Irish Family Records. 'Cosby', p. 281. www. Burkespeerage.com.

24. Geni. (2016) Francis Seymour Cosby. https://www.geni.com/people/Francis-Cosby/ 6000000013686352923.

25. Stirnet. Cosby 1. https://www.stirnet.com/genie/data/british/cc4aq/cosby1.php\#vic1.

26. The Peerage. Francis Seymour Cosby. http://www.thepeerage.com/p37463. htm\#i374622.

27. Burke's Peerage. Burke's Landed Gentry Irish Family Records. 'Cosby', p. 281. www. Burkespeerage.com.

28. Caledonian Mercury. (1768) Extract of a letter from Bressau, 1 August. 24 August. 2b. Collection: British Newspapers 1710-1965. www.findmypast.co.uk.

29. Freemasons. (1767) The constitutions of the ancient and honourable Fraternity of free and accepted masons. Containing their history, charges, regulations, \&c. [Compiled] by J. Anderson. Revised, with additions, by J. Entick, Volume 1. P. Ixx. https://books. google.co.uk/.

30. Freemasons. United Grand Lodge of England. (1777) The Free Masons calendar: for 1777. Being the first after leap-year. Published under the sanction of the Grand Lodge of England. p. 23. https://books.google.co.uk/.

31. World Through the Lens. (1995) Obscure old english occupations. http://www. worldthroughthelens.com/family-history/old-occupations.php.

32. London Land Tax Records. Tower. 1770. Francis Seymour Cosby. Collection: London Land Tax Records. London, England: London Metropolitan Archives. Call No: MS/16316/215. www.ancestry.co.uk.

33. London Land Tax Records. Tower. 1770. Francis Seymour Cosby. Collection: London Land Tax Records. London, England: London Metropolitan Archives. Call No: MS 11316/218. www.ancestry.co.uk.

34. London Land Tax Records. Tower. 1770. Francis Seymour Cosby. Collection: London Land Tax Records. London, England: London Metropolitan Archives. Call No: MS 11316/221. www.ancestry.co.uk.

35. London Land Tax Records. Tower. 1770. Francis Seymour Cosby. Collection: London Land Tax Records. London, England: London Metropolitan Archives. Call No: MS 11316/233. www.ancestry.co.uk.

36. London Land Tax Records. Tower. 1770. Francis Seymour Cosby. Collection: London Land Tax Records. London, England: London Metropolitan Archives. Call No: MS 11316/224. www.ancestry.co.uk.

37. London Land Tax Records. Tower. 1770. Francis Seymour Cosby. Collection: London Land Tax Records. London, England: London Metropolitan Archives. Call No: MS 11316/303. www.ancestry.co.uk.

38. Thompson, F. M. L. (1963) English landed society in the nineteenth century. London: Routledge \& Kegan Paul. p. 73.

39. Baptisms (PR) England. London. 28 November 1738. ROBERTS, Christopher John. Ref: TNA/RG/4/4408. Collection: England \& Wales Non-Conformist Births and Baptisms. www.findmypast.co.uk.

40. Testamentary Records England. 5 May 1806. ROBERTS, John Christopher. Will. Collection: Prerogative Court of Canterbury and Related Probate Jurisdictions: Will Registers; Class: PROB 11; Piece: 1443. www.ancestry.co.uk.

41. Gazette. (1828) Notices: John Christopher ROBERTS. No. 18493. 5 August 1828. https://www.thegazette.co.uk/London/issue/18493/page/1498. 
42. Powell, Martyn J. (2018) 'Roberts, John (1711/12-1772), politician.' In: Oxford Dictionary of National Biography. Oxford: Oxford University Press. http://www oxforddnb.com/view/10.1093/ref:odnb/9780198614128.001.0001/odnb9780198614128-e-23760.

43. Bowsher, Elizabeth. (2018) What is the value of the Equitable Life Assurance archive, 1763-1835? A genealogical and demographic study. Unpublished MSc Dissertation, University of Strathclyde. pp. 26-36.

44. Pearson, Robin. Thrift or dissipation? The business of life assurance in the early nineteenth century. (1990) The Economic History Review. 43(2). pp. 236-254. www. jstor.org/stable/2596788.

45. Marriages (PR) England. St Pancras, Camden, Middlesex. 22 May 1826. STEWART, Richard Hardinge and BUSCHMAN, Caroline. Repository: London Metropolitan Archives. Collection: London, England, Church of England Marriages and Banns, 1754-1932. Ref: p90/pan1/062. p. 430. www.ancestry.co.uk.

46. Burials (PR) England. St Pancras Chapel, London. 17 August 1833. STEWART, Caroline. Repository: London Metropolitan Archives. Collection: London, England Church of England Deaths and Burials, 1813-2003. Ref: p90/pan1/184. www. ancestry.co.uk.

47. Baptisms (PR) England. St Pancras, London. 22 August 1833. STEWART, Caroline Ann. Repository: London Metropolitan Archives. Collection: London, England, Church of England Births and Baptisms, 1813-1917. Ref: p90/pan1/018. www. ancestry.co.uk.

48. Measuring worth.com. Purchasing power of British pounds from 1270 to present. https://www.measuringworth.com/calculators/ppoweruk/.

49. Burials (PR) England. Cranleigh St Nicholas, Surrey. 16 April 1872. STEWART, Richard Hardinge. Collection: Surrey, England, Church of England Burials, 1813-1987. Ref: CRA/4/1. p. 165. www.ancestry.co.uk.

50. Deaths Index (CR) England \& Wales. Hambledon, Surrey. Q2 1872. STEWART, Richard Hardinge. Vol. 2a, p. 69. www.ancestry.co.uk.

51. London Metropolitan Archives. Equitable Life Assurance Archives, 1830-1950. Weekly Court of Directors Minutes: Reference Code: CLC/B/079/MS38646 Volume 21. 23 Aug 1871-20 Aug 1873 'no. 75 '. p. 234.

52. Testamentary Records. England. 12 April 1872. STEWART, Richard Hardinge, Probate Calendar. Collection: England \& Wales, National Probate Calendar (Index of Wills and Administrations), 1858-1966. www.ancestry.co.uk.

53. Baptisms (PR) England. St James, Middlesex. 5 October 1748. DAMER, Lionel. Repository: City of Westminster Archives Centre. Collection: Westminster Baptisms. www.findmypast.co.uk.

54. Burke, John. (1831). A genealogical and heraldic dictionary of the peerages of England, Ireland, and Scotland, extinct, dormant, and in abeyance. London: $\mathrm{H}$. Colburn \& R. Bentley. p. 156. www.books.google.co.uk.

55. Monumental Inscriptions. England. St Peter \& St Paul Church, Bromley, Kent SPARKES, Joseph. \{Notes]. Noted by Richard Holworthy. The British Archivists. Vol. 1. Sept 1914 to June 1915. Kent Archaeological Society. https://www.kentarchaeol ogy.org.uk/Research/Libr/Mls/MlsBromley/01.htm.

56. Gross, Jonathan David. (2013) The life of Anne Damer: portrait of a Regency artist Plymouth: Lexington Books. p. 16. www.books.google.com.

57. Gross, Jonathan David. (2013) The life of Anne Damer: portrait of a Regency artist Plymouth: Lexington Books. p. 31. www.books.google.com.

58. Babbage, Charles. (1826) A comparative view of the various institutions for the assurance of lives. London: For J. Mawman. pp. 26-29. https://archive.org/details/ acomparativevie01babbgoog.

59. Burials (PR) England. All Saints, Loughborough, Leicestershire. 12 January 1773. PARKINSON, Revd Thomas. Repository: Record Office for Leicestershire, Leicester \& Rutland. Collection: Leicestershire Burials. Ref: DE667/4. www.findmypast.co.uk

60. Testamentary Records. England. 1773. PARKINSON, Thomas. Administration. Collection: Leicestershire Wills and Probate Records, 1500-1939. Ref: 1773 C-Z www.findmypast.co.uk

61. Marriages (PR) England. All Saints, Loughborough, Leicestershire. 18 June 1776 CAPP, William and PARKINSON (alias CAPP), Mary. Repository: Record Office for Leicestershire, Leicester \& Rutland. Collection: Leicestershire Banns. Ref: DE667/11. www.findmypast.co.uk.

62. Baptisms (PR) England. All Saints, Loughborough, Leicestershire. 27 May 1757. PARKINSON, Mary. Repository: Record Office for Leicestershire, Leicester \& Rutland. Collection: Leicestershire Baptisms. Ref: DE667/4. p. 50. www.findmypast.co.uk.

63. Sheffield University. (2015) The Old Bailey Proceedings Online. Sixth Session 1834 p. 597. https://www.oldbaileyonline.org/images.jsp?doc=183407030085.

64. London Metropolitan Archives. (1833) Catalogue. Insured: Edward Byas and Sophia Poulain, The Workhorse, Bear Lane, Southwark. Ref: MS 11936/537/1153932. http:// discovery.nationalarchives.gov.uk/details/r/dcdf9d7b-16cf-4c1 e-97e2-5f6f8f49d317.
65. Roberts, Andrew. (1981) The Lunacy Commission - the 1832 Madhouse Act and the Metropolitan Commission in Lunacy from 1832. http://www.studymore.org.uk/3_06. htm.

66. Sheffield University. (2015) The Old Bailey Proceedings Online. Sixth Session 1840. p. 38. https://www.oldbaileyonline.org/images.jsp?doc $=184011230038$ : accessed 12 December 2018

67. Census 1841 England. Stratford Le Bow, Middlesex. HO107. PN: 695. Book: 5.ED: Grove Hall Establishment. p. 1. Line: 1. GSU roll: 438811. www.ancestry.co.uk.

68. Porter, David and Wright, David. (2003) The confinement of the insane: international perspectives, 1800-1965. Cambridge: Cambridge University Press. pp. 343-344. www.books.google.co.uk.

69. Marriages (PR) England. St Mary Stratford Bow, Middlesex. 11 May 1836. BYAS Edward and LOVIE, Mary Anne. Repository: London Metropolitan Archives. Collection: London, England, Church of England Marriages and Banns, 1754 -1932. Ref: p88/mry1/015. p. 154. www.ancestry.co.uk.

70. Deaths Index (CR) England \& Wales. Kensington, London. Q2 1866. BYAS Edward. Vol 1a, p. 44. www.ancestry.co.uk.

71. Testamentary Records. England \& Wales. 14 November 1866. BYAS, Edward. Probate Calendar. Collection: England \& Wales, National Probate Calendar (Index of Wills and Administrations), 1858-1966, 1973-1995. www.ancestry.co.uk.

72. London Metropolitan Archives. Equitable Life Assurance Archives, 1830-1950. Weekly Court of Directors Minutes: Reference Code: CLC/B/079/MS38646 Volume 21. 23 Aug 1871-20 Aug 1873 'no. 75'. pp. 112-113.

73. Testamentary Records. England. 12 March 1779. SHERBROOKE, Henry. Will. Collection: Prerogative Court of Canterbury (PCC) Wills, 1384-1858. Ref: PROB11/ 1051. www.TheGenealogist.co.uk.

74. The National Archives. Catalogue. Nottinghamshire Archives - 157DD/SK Sherbrooke of Oxton: Deed poll, release. 1) Catherine Bonel of Sutton Cofield Warks, widow. (Catalogue) http://discovery.nationalarchives.gov.uk/details/r/261f7cf97eac-4dc6-9119-f7be113d7ffo.

75. Langley, Leanne. (2000). 'Sainsbury's dictionary, the Royal Academy of Music, and the rhetoric of patriotism.' In: Bashford, Christina and Langley, Leanne. Music and British culture 1785-1914 - Essays in Honour of Cyril Ehrlich. Oxford: Oxford University Press. p. 70 fn. www.books.google.co.uk.

76. The Worshipful Company of Bowyers. Thomas Sainsbury Master 1774-1776, Lord Mayor 1786-1787. http://www.bowyers.com/personalities_sainsbury.php.

77. Ogborn, M. E. (1962) Equitable Assurances: the story of life assurance in the experience of the Equitable Life Assurance Society, 1762-1962. London: Routledge. p. 253.

78. The Society for Equitable Assurances on Lives and Survivorships. (1792) A short account. Society for Equitable Assurances on Lives and Survivorships. p. 11. www. books.google.co.uk.

79. Burials (PR) England. Market Lavington, Wiltshire. 26 May 1795. SAINSBURY, Thomas. Repository: Wiltshire and Swindon History Centre. Collection: Wiltshire, England, Church of England Baptisms, Marriages and Burials, 1538-1812. Ref: 836/ 3. www.ancestry.co.uk.

80. Testamentary Records. England. 3 June 1795. SAINSBURY, Thomas. Will. Collection: Prerogative Court of Canterbury and Related Probate Jurisdictions: Will Registers; Class: PROB 11; Piece: 1262. www.ancestry.co.uk.

81. Marriage Bonds (PR) England. St Botolph Aldersgate, London. 19 May 1777. PLAXTON, William and BONELL, Catherine. Collection: London and Surrey, England, Marriage Bonds and Allegations, 1597-1921. Ref: MS 10091E/90. www. ancestry.co.uk.

82. Marriage Bonds (PR) England. St Botolph Aldersgate, London. 19 May 1777. PLAXTON, William and BONELL, Catherine. Collection: London and Surrey, England, Marriage Bonds and Allegations, 1597-1921. Ref: DL/A/D/006/MS10091/ 138. www.ancestry.co.uk.

83. Marriage Bonds (PR) England. St Ethelburga Bishopsgate, City of London. 22 September 1779. PLAXTON, William and BONELL, Catherine. Collection: London and Surrey, England, Marriage Bonds and Allegations, 1597-1921. Ref: MS 10091/ 142. www.ancestry.co.uk.

84. Marriages (PR) England. St Ethelburga Bishopsgate, City of London. 3 October 1779. PLAXTON, William and BONELL, Catherine. Repository: London Metropolitan Archives. Collection: London, England, Church of England Marriages and Banns, 1754-1932. Ref: P69/ETH/A/01/Ms 4237. www.ancestry.co.uk.

85. Testamentary Records. England. 12 March 1779. SHERBROOKE, Henry. Will. Collection: Prerogative Court of Canterbury (PCC) Wills, 1384-1858. Ref: PROB11/ 1051. www.TheGenealogist.co.uk.

86. Marriages (PR) England. St Martin Ludgate, City of London. 19 August 1756. SAINSBURY, Thomas and PREACHER, Ann. Repository: London Metropolitan Archives. Collection: London, England, Church of England Marriages and Banns, 1754-1932. Ref: P69/MTN1/A/01/Ms 10216/1. www.ancestry.co.uk. 
87. Burials (PR) England. St Martin, Ludgate, City of London. 24 January 1776. SAINSBURY, Ann. Repository: London Metropolitan Archives. Collection: London, England, Church of England Baptisms, Marriages and Burials, 1538-1812. Ref: P69/ MTN1/A/003/MS10214. www.ancestry.co.uk.

88. Marriages (PR) England. St Martin Ludgate, City of London. 31 October 1777. SAINSBURY, Thomas and EVEBUGH, Mary. Repository: London Metropolitan Archives. Collection: London, England, Church of England Marriages and Banns, 1754-1932. Ref: P69/MTN1/A/01/Ms 10216/1. www.ancestry.co.uk.

89. Derby Mercury. (1779) 'On Friday Evening arrived at their Seat at Duffield...'. 8 October. p. 3a. Collection: British Newspapers, 1710-1965. www.findmypast.co.uk.

90. Bucholz, R. O. (2005) The Database of Court Officers 1660-1837: Master Index, 'P'. http://courtofficers.ctsdh.luc.edu/

91. HMSO. (1831) Parliamentary Papers: 1780-1849, Volume 3. London: HMSO. p. 59 www.books.google.co.uk.

92. The Bednall Archive. (2004) References to the Cruso family of Leek in the Bednall Collection. Item: BC1/ 760. http://www.bednallarchive.info/referncs/cruso_ref.htm.

93. Thoroton, Robert and Throsby, John. (1797) Thoroton's history of Nottinghamshire. p. $277 \mathrm{fn}$. www.books.google.co.uk.

94. The National Archives. Catalogue. C - Records created, acquired, and inherited by Chancery, and also of the Wardrobe, Royal Household, Exchequer and various commissions: Court of Chancery: Six Clerks Office: Pleadings 1758 to 1800 Bonnell v Plaxton, C 12/437/7 http://discovery.nationalarchives.gov.uk/details/r/ C9569594

95. The National Archives. Catalogue. C - Records created, acquired, and inherited by Chancery, and also of the Wardrobe, Royal Household, Exchequer and various commissions: Court of Chancery: Six Clerks Office: Pleadings 1758 to 1800 - Plaxton v Sainsbury, C 12/1066/10. http://discovery.nationalarchives.gov.uk/details/r/ C9602808.

96. The National Archives. Catalogue. C - Records created, acquired, and inherited by Chancery, and also of the Wardrobe, Royal Household, Exchequer and various commissions: Court of Chancery: Six Clerks Office: Pleadings 1758 to 1800 - Bonnell v. Plaxton, C 12/181/16. http://discovery.nationalarchives.gov.uk/details/r/C9547016.

97. The National Archives. Catalogue C - Records created, acquired and inherited by Chancery, and also of the Wardrobe, Royal Household, Exchequer and various commissions: Court of Chancery: Six Clerks Office: Pleadings 1758 to 1800 - Bonell v Harborne. http://discovery.nationalarchives.gov.uk/details/r/C16352941.

98. Institute and Faculty of Actuaries. Equitable Life Assurance Society Archive, 1762 -1835: EL/4/5/1, Alphabet Index, 1762-1773, p. 154, 'Ro'.

99. Institute and Faculty of Actuaries. Equitable Life Assurance Society Archive, 1762 -1835: EL/4/5/2, Alphabet Index, 1774-1791, p. 157, 'Ro'.

100. Roberts, Christopher John. (1777) The case of the Commissary General of provisions and stores for the Province of Quebec, in North America. Orig. Fielding \& Walker. Reproduction from British Library. Gale ECCO Print Edition. p. 1.

101. American Revolution.org. (1996) The organization of the British Army in the American Revolution. Chapter IV, Section 2: 2, America as a Source of Provisions. https://www. americanrevolution.org/britisharmy4.php.

102. Encyclopaedia Britannica. Early British rule, 1763-91: The Quebec Act. https://www. britannica.com/place/Canada/Early-British-rule-1763-91.

103. Roberts, Christopher John. (1777) The case of the Commissary General of provisions and stores for the Province of Quebec, in North America. Orig. Fielding \& Walker. Reproduction from British Library. Gale ECCO Print Edition. p. 1

04. Gentleman's Magazine. 1768. ROBERTS, John Christopher. July. www.ancestry.co.uk

105. Roberts, Christopher John. (1777) The case of the Commissary General of provisions and stores for the Province of Quebec, in North America. Orig. Fielding \& Walker. Reproduction from British Library. Gale ECCO Print Edition. p. 10.

106. Roberts, Christopher John. (1777) The case of the Commissary General of provisions and stores for the Province of Quebec, in North America. Orig. Fielding \& Walker. Reproduction from British Library. Gale ECCO Print Edition. p. 20.

107. British India Office Army \& Navy Pensions (Great Britain). Lord Clive Military Fund Pension Registers \& Payment Books - widows in Madras. 1770. ROBERTS, John Christopher. Ref: L-AG-23-2-3. www.findmypast.co.uk.
108. The National Archives. (1773) Catalogue: NORTH AMERICA: Colonies: Quebec: Memorial of John Christopher Roberts. http://discovery.nationalarchives.gov.uk/ details/r/C7661320

109. Parliamentary Archives. Quebec Act, 1774. https://www.parliament.uk/about/livingheritage/evolutionofparliament/legislativescrutiny/parliament-and-empire/collec tions1/collections1/quebec-act/.

110. The Canadian Encyclopaedia. (2018) Quebec Act. https://www.thecanadianencyclo pedia.ca/en/article/quebec-act.

111. Roberts, Christopher John. (1777) The case of the Commissary General of provisions and stores for the Province of Quebec, in North America. Orig. Fielding \& Walker. Reproduction from British Library. Gale ECCO Print Edition. p. 3.

112. Roberts, Christopher John. (1777) The case of the Commissary General of provisions and stores for the Province of Quebec, in North America. Orig. Fielding \& Walker. Reproduction from British Library. Gale ECCO Print Edition. pp. 3-4.

113. History.com. Battle of Quebec: 1775. https://www.history.com/topics/american-revo lution/battle-of-quebec-1775.

114. History.com. Battle of Quebec: 1775. https://www.history.com/topics/american-revo lution/battle-of-quebec-1775

115. The Canadian Patriot. (2017) The Unveiling of Canadian History Vol 3: FORLORN HOPE - Quebec and Nova Scotia, and the War for Independence. http://canadianpa triot.org/the-unveiling-of-canadian-history-vol-3-the-road-to-canada-1774-1789/.

116. The Monthly Review; or Literary Journal. (1778) Miscellaneous. Article 34: The Case of the Commissary General of Provisions and Stores of the Province of Quebec. pp. 162-63. https://books.google.co.uk.

117. Roberts, Christopher John. (1777) The case of the Commissary General of provision and stores for the Province of Quebec, in North America. Orig. Fielding \& Walker. Reproduction from British Library. Gale ECCO Print Edition. pp. 3-4.

118. Roberts, Christopher John. (1777) The case of the Commissary General of provision and stores for the Province of Quebec, in North America. Orig. Fielding \& Walker. Reproduction from British Library. Gale ECCO Print Edition. p. 5.

119. History.com. Battle of Quebec: 1775. https://www.history.com/topics/american-revo lution/battle-of-quebec-1775

120. Roberts, Christopher John. (1777) The case of the Commissary General of provisions and stores for the Province of Quebec, in North America. Orig. Fielding \& Walker. Reproduction from British Library. Gale ECCO Print Edition. pp. 6-10.

121. Roberts, Christopher John. (1777) The case of the Commissary General of provision and stores for the Province of Quebec, in North America. Orig. Fielding \& Walker. Reproduction from British Library. Gale ECCO Print Edition. pp. 20-22.

122. Testamentary Records England. 5 May 1806. ROBERTS, John Christopher. Will. Collection: Prerogative Court of Canterbury and Related Probate Jurisdictions: Will Registers; Class: PROB 11; Piece: 1443. www.ancestry.co.uk.

123. Testamentary Records England. 5 May 1806. ROBERTS, John Christopher. Will. Collection: Prerogative Court of Canterbury and Related Probate Jurisdictions: Will Registers; Class: PROB 11; Piece: 1443. www.ancestry.co.uk.

124. Gazette. (1828) Notices: John Christopher ROBERTS. No. 18493. 5 August. https:// www.thegazette.co.uk/London/issue/18493/page/1498.

125. Institute and Faculty of Actuaries. Equitable Life Assurance Society Archive 1762-1975: Catalogue. https://www.actuaries.org.uk/learn-and-develop/research-and-knowl edge/library-services/historical-collections/archive-equitable-life-assurance-society.

126. Institute and Faculty of Actuaries. Equitable Life Assurance Society Archive 1762 -1975: Catalogue. https://www.actuaries.org.uk/learn-and-develop/research-andknowledge/library-services/historical-collections/archive-equitable-life-assurancesociety. EL 4/5/1-6. pp. 26-27.

127. Institute and Faculty of Actuaries. Equitable Life Assurance Society Archive 1762 -1975: Catalogue. https://www.actuaries.org.uk/learn-and-develop/research-andknowledge/library-services/historical-collections/archive-equitable-life-assurancesociety.EL 1/2/1-55. pp. 8-13.

128. Institute and Faculty of Actuaries. Equitable Life Assurance Society Archive 1762 -1975: Catalogue. https://www.actuaries.org.uk/learn-and-develop/research-andknowledge/library-services/historical-collections/archive-equitable-life-assurancesociety. EL4/3/1. p. 24

\section{ABOUT THE AUTHOR}

Elizabeth Bowsher, LLB, MSC (Genealogical Studies) is a former senior civil servant from the Department of Health (England). She has a long-held interest in genealogy and more recently has worked as an independent researcher and genealogist. She obtained the MSc at the University of Strathclyde in 2018.

Email: lizbowsher@qualifiedgenealogists.org 